IJIET, e-ISSN 2548-8430, p-ISSN 2548-8422, Vol. 1, No. 2, July 2017

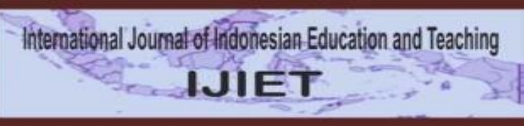

International Journal of Indonesian Education and Teaching http://e-journal.usd.ac.id/index.php/IJIET

Sanata Dharma University, Yogyakarta, Indonesia

\title{
DEMOCRATIC EDUCATION THROUGH HISTORY LEARNING USING SOCIAL HISTORY TEACHING MATERIALS
}

\author{
Hendra Kurniawan \\ Sanata Dharma University \\ hendrak@usd.ac.id \\ https://doi.org/10.24071/ijiet.2017.010205 \\ received 6 April 2017; revised 27 May 2017; accepted 25 June 2017
}

\begin{abstract}
The democracy practice could grow when the nation's generation had history awareness and be a good citizen. So the democratic education should be developed, one of the ways was through history learning in schools. Social historyteaching materials, especially regarding women and ethnic was full of democratic values, there were freedom and egalitarian. Various experiences and problems of democracy could not be separated from society life since ancient era. By understanding the social dynamics through history learning, the young generation was expected to be wise in determining the democracy continuity for nation's future.
\end{abstract}

Keywords: democratic education, history learning, teaching materials, social history

\section{Introduction}

Education plays a fundamental role in personal and societal development. It must be realized that education is not just a brain matter, but also value implantation for character building. One of the universal values that deserve attention is democracy. Let alone, there are efforts that could potentially threaten the democracy development in Indonesia until now. So the democratic attitudes must continuously develop, especially on young generation through education.

Implantation of democratic values in education has explicitly regulated by Law No. 20 of 2003 on the National Education System (Sisdiknas) in Article 3 which states that

National education has function to develop the ability, character building and nation's civilization that were dignified in the context of enrich the nation's life, aimed at developing students' potentials in order to be a people that are faith and fear of God Almighty, noble, healthy, knowledgeable, skilled, creative, independent and be a democratic and responsible citizens.

Still in that law, democratic education is reinforced in Article 4 Paragraph (1) that reads "Education should be implemented democratically, fair and not discriminate to uphold human rights, religious values, cultural values, and the nation's diversity". Realizing the nation's diversity, tolerance and mutual respect 
attitudes become mutual needs. This is the essential role of democratic education. Pancasila and Citizenship Education (PPKn) are the most relevant subjects as a means of democratic education in learning at school, but most likely also through history subjects.

Democratic education in history learning can be done by using appropriate teaching materials. Teaching materials are developed more in-depth by instilling democratic education. Teaching materials are helpful to achieve the learning objectives and also a means to achieve a high level understanding for students. The teacher as a facilitator in the learning activities must have a good understanding about the teaching materials so they can internalize the value of students properly.

History learning should be able to develop students' thinking ability, so the use of teaching materials as much as possible provides space for students to be active and critical. Students are challenged to find sources of learning to gather information independently and critically reviewed. One of the ways is by applying constructivist history learning. It will give a freedom for students to gain experience in direct and meaningful learning. Therefore, it does not only implant the democratic values, but also the democratic nuanced learning process.

This paper discusses democratic education through history learning by using teaching materials contained social history. Social history topics contained democratizing value, especially freedom and egalitarian, emphasized on women's history and ethnic minority history in Indonesia. These two topics review communities who experience marginalization and rarely take a place on national history. Both of them are expected to grow democracy passion in pluralistic society daily lives.

\section{Theory}

\section{Democracy and Democratic Education}

Democracy is etymologically derived from the Greek demos meaning people and kratos/cratein meaning governance. From this sense, it appears that democracy in the narrow sense is closely related to the state affairs and power. In the development, democracy is not only as a form of government or political system but also has become a life attitude. Dahl $(2001: 68,70)$ mentions that "democracy essentially is also a system of rights. ... Democracy guarantees a wider personal freedom for citizens". Democracy is expected not only to fulfill the civil and political rights, but also include economic, social, and cultural systems inbroader sense (Herdiawanto and Hamdayama, 2010: 82).

Latif (2011: 383) affirms that the United Nations from multicultural nationality like Indonesia can survive if there is a balance in the fulfillment of liberty, equality, and fraternity principles among nation's elements. It's not only individual rights and society (collective rights) fulfillment, but also the obligation to develop social solidarity (mutual cooperation) for the nation's benefit. Civil society can be realized through the democratic process.

Democracy basically acknowledges each person as a unique, typical individual, and different from each other. In a democracy, every person is given freedom to implement and develop their potential. Democracy has 10 pillars, 
namely (1) popular sovereignty, (2) government based on the consent of the governed, (3) majority's power (the election results), (4) minority rights guarantee, (5) human rights guarantee, (6) equality before the law, (7) fair legal process, (8) governmental power limitation through the constitution, (9) pluralism of social, economic and politic, and (10) the development of tolerance, pragmatism, cooperation, and agreement values (Ubaedillah \& Rozak, 2003: 71).

The growth of democratic value can be done through democratic education. Democratic education puts students as different and unique individuals to develop the existing potentials maximally. The essence of democratic education is todevelop the human existing through equality of dignity, mutual trust, tolerance, mutual respect and honor, active participation in various aspects of social life, andfreedom (Citizenship Education Lecturer National Team, 2010: 139). The content of the various values is expected to be internalized through history learning by using social history materials.

Democratic education cannot be separated from the democratic learning process. The learning process that takes place in the classroom is dynamic. The dynamic learning process in the classroom seen by the interaction between teachers and students, students and other students, students and sources and teaching materials available. These interactions led by the teacher as a facilitator and motivator. Student-friendly learning and putting student as a study subject became the start of democratic learning realization.

Democratic learning will create a fun learning environment. Teachers are expected to lead the students to learn mutual respect, support, and provide opportunities to each other. If students obtained meaningful learning experiences with the democratic nuances, the learning objectives can be achieved more leverage. Democratic values will also be more easily internalized in students.

Democratic value cultivation can be done by constructivist learning approach. Suparno (1997: 62) explains that by using it, students are given a freedom to build knowledge independently by finding significance. Further Suparno (1997: 66) explains that the teacher as facilitator and mediator must provide learning experiences for students, provide activities that stimulate students' curiosity, monitor and evaluate the knowledge building by the student at the same time. So teachers should be prepared and mastered teaching material both formal (contained in textbooks) and informal (outside textbooks or materials development).

In democratic education, students and teachers can discuss and review the topics raised by teachers or students when learning takes place. Therefore the lesson should not be exactly the same as teacher's planning in the learning media. Teachers should be prepared to make teaching materials development that can also support the democratic values cultivation to students.

\section{Social History Teaching Materials for Democratic Education}

According to Ibrahim and Syaodih (2002: 100), teaching materials are something served by teacher and then processed and understood by students in order to achieve instructional objectives have been set. Teaching material consists of facts, generalizations, concepts, laws or rules, etc. contained in the subjects. Dakir (2004: 14) also explains on developing teaching materials, teacher should 
pay attention to the following (1) pedagogical; (2) psychological, interests and students' needs; (3) easily taught; (4) sociological or in accordance with the surrounding community situation; and (5) not contrary to the various provisions of the applicable legislations.

Development of teaching materials becomes important in the context of democratic learning nuances. It is aimed to give more space to develop students' critical thinking skills as expected in Curriculum 2013. In line with Article 4 Paragraph (1) of Law Number 20 Year 2003 on National Education System, the teaching materials development are also made on basic education that are democratic, fair and not discriminative by uphold human rights, religiosity, cultural and national diversity. History teaching materials are full of these values. This is what makes the history teaching materials development needs to be done within the democratic education framework.

History teaching materials according to Djoko Suryo in Aman (2011:97) may start from some study fields: (1) history of thought and religious philosophy,

(2) history of civilization and culture, (3) national and local history, (4) social or society history, and (5) Indonesia's constitutional history that gives democracy understanding and civil society formation. The idea of history teaching materials development is in line with the outlined of National Education System Law regarding democratic education.

This paper offered several proposals of history teaching materials development that teachers can do. The proposal presented focuses on social history theme or society history and then reviews the democratic values content init. These materials are expected to be integrated into the basic competence in accordance with Indonesian History syllabus (required) in Curriculum 2013 for high school (SMA/MA/SMK). It is focused on Indonesian history considering that this subject focuses on the value implantation to all students of all specializations.

History learning had been dominated by political themes all this time. Political discussions can't be separated from the 'ruling class' problem, a minority that holds power in every society and the state over people(Onghokham, 1991: 100). Even though society social structure also needs attention in history, from theelite, aristocrats, merchants, farmers, laborers, artist, the poor, the homeless, and the criminals (Suhartono, 2010: 68). This is examined by social history as history from below centered on particular groups and the underprivileged that will complete the dynamics overview and Indonesian society development widely, completely and continuously (Aman, 2011: 98).

Kartodirdjo (1992: 158) describes the social history as a history of various social movements, including the movement of peasants, workers, students, protest, etc. Social history can also include demographic history such as population growth and migration. Social history also includes the social group's development and their lifestyles from elite class to underdog (marginal groups).

The peasant movement in the colonial period included Banten peasant rebellion in 1888, the peasant movement in Ciomas in 1886, 'Entong Gendut' rebellion in Tanjung Oast in 1916, etc. Moreover, the appearance of 'Ratu Adil' movement that was messianic by expecting the arrival of Ratu Adil (Imam Mahdi/ Savior), Religious Sects Movement, and the Islamic Sarikat Movement in the 
countryside. These social movements can be presented on the materials of resistance against colonial rule.

Prijaji's lifestyle and Indies cultural development also be a study of social history associated to Dutch colonization influence. Soekiman (2000: 27-28) explains that the Indo (crossbreed between native and Dutch) attempted to create their own culture and even social class called Indies. The Indo felt caught between two social-culture spheres, Dutch and natives. Indies' social and cultural group they created also accommodated the social struggle faced by the Javanese prijaji. This material can be a description how feudalistic elements that restrict the democracy are so exalted even today.

On the national movements' materials, movements doing by various groups of society such as women, ethnic, or religious beliefs also include the study of social history. Discussion about these groups is not as much as the discussion about nationalists. Sartono Kartodirdjo in Mulyana and Darmiasti (2009: 5) explains that the Indonesian history should be a "history from the inside", that reveals the activity of various society groups, and lead to the nation's integration. So, history teaching materials should contain the dynamics of various societies, not just the dominance of certain groups.

For example, a place for social history that examines the life dynamics of various societies from the elite to underdog is a part of democratic education. In the development of nation's history, at least three social issues are important to note as the study of democratic education, there are women, ethnic and religious. Religious groups have gotten sufficient and balanced portions so far. However, the role of women and ethnic minorities is still less addressed. These two focuses can encourage democratic awareness, especially freedom and equality so harmonious society will be created.

\section{Theory Application Women's History}

History had long been dominated by men. Suhartono (2010: 93) says the history tends to be androcentric because it talks a lot about power, government, war, politics, the military, etc. Women only became the object and the secondary sex. Around the 20th century, a gender movement that wants to fight for the position and dignity of women emerged. The dichotomy between men and women inadvertently had made the subordination of women by men. As a result of this binary opposition, men were more exposed in the public sector, while women were in the domestic sector.

There are many women history's themes that can be developed from oppression and discrimination problems until the emergence of female warrior figures. Long before colonialism came to rule, Javanese women were treated as 'kanca wingking', a status which placed women as merely men's companion in private areas. A wife's fate totally depended on her husband. The term wasswarga nunut, neraka katut (Sarwono, 2004: xi) or "to heaven or to hell, a wife follows her husband either way". The coming of Dutch colonialism draggedwomen to the concubinage practice that increasingly demeaned women (Hellwig, 
2007; Baay, 2010). Reviewing women's position in the historical dynamics can raise the awareness of the importance of equality between men and women.

The role of women figures in the Indonesian history is actually quite significant and some of them have taken place in history teaching materials. For example are Ratu Sima, the famous ruler of Kalinga kingdom that was fair and firm, the bravery of Queen Kalinyamat Queen from Demak, till the struggle of R.A. Kartini presumably familiar to be given. But there are many women fighters that should be studied such as Cut Nyak Dien, Cut Meutia, Martha Christina Tiahahu, Maria Walanda Maramis, Dewi Sartika, Rohana Kudus, and others.

Women also played a role in the independence period, for example Soerastri Karma Trimurti, a three period journalist who became the Minister of Labour during the Old Order; Maria Ulfah Santoso, BPUPKI (Independence Preparation Body) members who became the Minister of Social Affairs in Sjahrir's Cabinet; and others. The 1965 incident that dragged Gerwani made women in the New Order tended to be apolitical and experiencing de-radicalization. Then women were accommodated in organizations such as Family Welfare Guidance or Pembinaan Kesejahteraan Keluarga (PKK/Family Welfare Supervision), DharmaWanita, Dharma Pertiwi, and others that were formed as a result of the existenceor their husbands' status. The ups and downs need to be studied to grow the spirit of freedom and gender equality importance.

\section{Ethnic History}

Suhartono (2010: 92) mentions the ethnic history as ethnohistory. The scope of etnic history concerns social, economic, cultural, trust relations, and social change aspects. Indonesia is very diverse society made up of various tribes who had always live together. Before the state forming, the Indonesian people had existed. It was formally stated in the Youth Pledge or Sumpah Pemuda on October28, 1928. Anderson (2001: 8) describes the nation as an imagined community because their members do not recognize most of the other members, not face to face, do not even hear about the other members, but in the mind of every nation's member living a shadow about their togetherness.

According to Kartodirdjo (1995: 4), national history truly is a unit consisting of the complexity of ethnic, linguistic, religious, cultural, judicial elements, etc. manifested as a unity through historical development process. Including ethnic groups considered as newcomers such as Chinese, Arabic, Indian, and so on have a role in the Indonesian national history. One of the very rarely mentioned is the Chinese. Even though Chinese is the most numerous newcomers scattered in various regions of Indonesia and became the most frequent citizens who fall victims to any political and cultural conflicts.

According to Setiono (2008: 21), the Chinese began to come to the archipelago in the 9th century, during the Tang Dynasty. They came to look for a better life by trading or farming. Kong (2005: 1-12) even mentions the majority of the Indonesian people came from Yunnan in the southwest of China. They spread into Proto-Malays and Malays Deutro so there was blood relation between the Chinese and most of Indonesian tribes. Actually, the problem of being indigenious or not indigenious, natives-non-natives is not very relevant to be discussed. Anthropologically, Indonesian residents today are non-natives. The difference is 
only the time of their ancestors began arriving to inhabit the archipelago (Setiono, 2008: 16).

Chinese Ethnics in Indonesia had a long history. Long before the Dutch came, the Chinese people had traded and established business relationship in the archipelago. The Chinese also took a role in the Islamic development, for example in the Admiral Zheng He's story. This material can be taught on 'the coming and development of Islam in Indonesia' subject. In the Dutch colonial period, the Chinese's motion was narrowed on trading by the zoning stay (wijkenstelsel) that was a Chinatown and the passes system (passenstelsel). The massacre tragedy happened on Chinese in Muara Angke in 1740 also needs to be studied. These events impacted on the outbreak of Geger Pacinan in 1740-1743 when Java's irregulars merging with the Chinese against the Netherlands.

At the Indonesian national movement era, the Chinese also had a role. In 1900 in Batavia, Bogor, Sukabumi, and other cities emerged Jong Chineesche Beweging movement or Chinese Youth Movement that had never been told. Inthe Youth Pledge or Sumpah Pemuda dated October 28, 1928, some Chinese werealso present in the pledge. They were Kwee Thiam Hong (David Budiman), Khai Ong Siang, Jong Liauw Tjoan Hok, Tjio Jin Kwee, and Muhammad Chai (Setiono, 2008: 504).

Starting from the nationalism spirit, the Chinese people also rose to fight for their fate as a result of Dutch colonialism by establishing Tiong Hoa Hwee Koan (THHK) and Sin Po Newspapers. THHK formed in March 17, 1900 played a major role in education in Indonesia by establishing schools (there were 54 schools in 1908 and reached 450 schools in 1934). There was Chung Hua Hui (CHH) group that more oriented to the Dutch East Indies by entering into the Volksraad. Indonesian national awareness was growing among the Chinese's descendant, and then they stood Indonesian Chinese Party or Partai Tionghoa Indonesia (PTI) that were determined to fight for the people fate together with the other nationalist organizations and fought for Indonesia's independence.

In preparing for the Indonesia's independence, some of Chinese also played a role. There were four Chinese figures became BPUPKI members namely Liem Koen Hian, Oei Tiang Tjoei, Oei Tjong Hauw and Eng Tan Hoa. In PPKI also recorded name Tjwan Bing Yap. In the Old Order, some Chinese politicians played a role in government such as Oei Tjoe Tat, Siauw Giok Tjhan, till Rear Admiral (Ret) John Lie Tjeng Tjoan, alias Jahja Daniel Dharma. John Lie became the first national hero from Chinese community for his services to quell the separatists from South Maluku Republic (RMS) and the PRRI / Permesta.

In the New order, this case was never raised. Even, discriminatory practice against Chinese ethnic groups is rampant even until today. Reformasi era was a turning point for the Chinese ethnic groups to re-participate in many facets of life including politics. By studying the history of Chinese people, students are expected to cultivate mutual respect and accept the existence of Chinese ethnic groups as part of Indonesian peoples. This is important in the democratic education framework that develops egalitarian spirits for the younger generation and avoids inter-ethnic conflicts at once. 


\section{Conclusions}

Democratic education is closely related to the students' character building. It is expected to realize a multicultural society that leads to the civil society formation. If lately there were attempts from certain parties that lead to the democracy deterioration, it was certainly unfortunate. The attitudes threaten the democracy should not be happened when this nation's generation has historyawareness and good citizen attitude. Observing this fact, democratic education is increasingly important and urgent to be implemented.

Democratic education through history learning teaches various democratic experiences in the past with various problems. It can be done by teaching materials development of social history or society history that contains democracy value. Especially on the study of women's history and ethnic groups that have tended to be discredited as marginal group. It will boost awareness that democracyrequires a long struggle and not an easy process. Later, the younger generations are expected to be wise in determining democracy.

\section{References}

Aman. (2011). Model evaluasi pembelajaran sejarah. Yogyakarta: Penerbit Ombak.

Anderson, B. (2001). Imagined communities: Komunitas-komunitas terbayang. Yogyakarta: INSIST.

Anonymous. (1995). Kebangsaan, Sejarah Nasional, dan Proses Integrasi. Dalam P.J.Suwarno (Eds.), Seri Proklamasi: Negara dan nasionalisme Indonesia, 410. Jakarta: PT Grasindo.

Baay, R. (2010). Nyai dan pergundikan di Hindia Belanda. Jakarta: Komunitas Bambu.

Benny, G.S. (2008). Tionghoa dalam pusaran politik. Jakarta: TransMedia.

Dahl, R.A. (2001). Perihal demokrasi: Menjelajahi teori dan praktek demokrasi secara singkat. Jakarta: Yayasan Obor Indonesia.

Dakir. (2004). Perencanaan dan pengembangan kurikulum. Jakarta: Rineka Cipta.

Djoko, S. (2000). Kebudayaan indis dan gaya hidup masyarakat pendukungnya di Jawa (Abad XVIII-Medio Abad XX). Yogyakarta: Yayasan Bentang Budaya bekerja sama dengan Yayasan Adikarya IKAPI dan The Ford Foundation.

Hellwig, T. (2007). Citra kaum perempuan di Hindia Belanda. Jakarta: Yayasan Obor Indonesia.

Herdiawanto, H., \& Hamdayana, J. (2010). Cerdas, kritis, dan aktif berwarganegara. Jakarta: Penerbit Erlangga.

Ibrahim, R. \& Syaodih, N. (2002). Perencanaan pengajaran. Jakarta: Rineka Cipta.

Kartodirdjo, S. (1992). Pendekatan ilmu sosial dalam metodologi sejarah. Jakarta: Gramedia Pustaka Utama.

Latif, Y. (2011). Negara paripurna: Historisitas, rasionalitas, dan aktualitas pancasila. Jakarta: PT Gramedia Pustaka Utama.

Mulyana, A., \& Darmiasti. (2009). Historiografi di Indonesia: Dari magisreligius hingga strukturis. Bandung: Refika Adhitama.

Onghokham. (1991). Rakyat dan negara. Jakarta: Pustaka Sinar Harapan. 
IJIET Vol. 1, No. 2, July 2017

Sarwono, S.W. (2004). Kata pengantar. Dalam Christina S. Handayani dan Ardhian Novianto, Kuasa Wanita Jawa (hlm. ix-xi). Yogyakarta: LkiS.

Silabus Mata Pelajaran Sejarah Indonesia (wajib) Kurikulum 2013 untuk SMA/MA Kelas X, XI, XII.

Suhartono. (2010). Teori dan metodologi sejarah. Yogyakarta: Graha Ilmu. Suparno, Paul. (1997). Filsafat konstruktivisme dalam pendidikan. Yogyakarta: Penerbit Kanisius.

Tim Nasional Dosen Pendidikan Kewarganegaraan. (2010). Pendidikan kewarganegaraan: Paradigma terbaru untuk mahasiswa. Bandung: Alfabeta.

Ubaedillah, A., \& Rozak, A. (2013). Pancasila, demokrasi, HAM, dan masyarakat madani. Jakarta: ICCE UIN Syarif Hidayatullah dan Penerbit Prenada Media Group.

Undang-Undang Republik Indonesia Nomor 20 Tahun 2003 tentang Sistem Pendidikan Nasional.

Yuanzhi, K. (2005). Silang budaya Tiongkok Indonesia. Jakarta: PT Bhuana Ilmu Populer. 